\title{
Front Matter: Volume 8763
}

, "Front Matter: Volume 8763," Proc. SPIE 8763, Smart Sensors, Actuators, and MEMS VI, 876301 (30 May 2013); doi: 10.1117/12.2029711

SPIE. Event: SPIE Microtechnologies, 2013, Grenoble, France 


\section{PROCEEDINGS OF SPIE}

\section{Smart Sensors, Actuators, and MEMS VI}

Ulrich Schmid

José Luis Sánchez de Rojas Aldavero

Monika Leester-Schaedel

Editors

24-26 April 2013

Grenoble, France

Sponsored and Published by

SPIE

Volume 8763

Proceedings of SPIE 0277-786X, V. 8763

SPIE is an international society advancing an interdisciplinary approach to the science and application of light.

Smart Sensors, Actuators, and MEMS VI, edited by Ulrich Schmid, José Luis Sánchez de Rojas Aldavero, Monika Leester-Schaedel, Proc. of SPIE Vol. 8763, 876301 - () 2013 SPIE

CCC code: $0277-786 X / 13 / \$ 18 \cdot$ doi: $10.1117 / 12.2029711$

Proc. of SPIE Vol. $8763876301-1$

Downloaded From: https://www.spiedigitallibrary.org/conference-proceedings-of-spie on 26 Apr 2023 Terms of Use: https://www.spiedigitallibrary.org/terms-of-use 
The papers included in this volume were part of the technical conference cited on the cover and title page. Papers were selected and subject to review by the editors and conference program committee. Some conference presentations may not be available for publication. The papers published in these proceedings reflect the work and thoughts of the authors and are published herein as submitted. The publisher is not responsible for the validity of the information or for any outcomes resulting from reliance thereon.

Please use the following format to cite material from this book:

Author(s), "Title of Paper," in Smart Sensors, Actuators, and MEMS VI, edited by Ulrich Schmid, José Luis Sánchez de Rojas Aldavero, Monika Leester-Schaedel, Proceedings of SPIE Vol. 8763 (SPIE, Bellingham, WA, 2013) Article CID Number.

ISSN: 0277-786X

ISBN: 9780819495600

Published by

SPIE

P.O. Box 10, Bellingham, Washington 98227-0010 USA

Telephone +1 3606763290 (Pacific Time) · Fax +1 3606471445

SPIE.org

Copyright (C) 2013, Society of Photo-Optical Instrumentation Engineers.

Copying of material in this book for internal or personal use, or for the internal or personal use of specific clients, beyond the fair use provisions granted by the U.S. Copyright Law is authorized by SPIE subject to payment of copying fees. The Transactional Reporting Service base fee for this volume is $\$ 18.00$ per article (or portion thereof), which should be paid directly to the Copyright Clearance Center (CCC), 222 Rosewood Drive, Danvers, MA 01923. Payment may also be made electronically through CCC Online at copyright.com. Other copying for republication, resale, advertising or promotion, or any form of systematic or multiple reproduction of any material in this book is prohibited except with permission in writing from the publisher. The CCC fee code is 0277-786X/13/\$18.00.

Printed in the United States of America.

Publication of record for individual papers is online in the SPIE Digital Library.

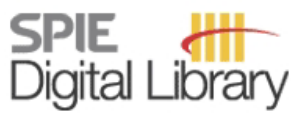

SPIEDigitalLibrary.org

Paper Numbering: Proceedings of SPIE follow an e-First publication model, with papers published first online and then in print and on CD-ROM. Papers are published as they are submitted and meet publication criteria. A unique, consistent, permanent citation identifier (CID) number is assigned to each article at the time of the first publication. Utilization of CIDs allows articles to be fully citable as soon as they are published online, and connects the same identifier to all online, print, and electronic versions of the publication. SPIE uses a six-digit CID article numbering system in which:

- The first four digits correspond to the SPIE volume number.

- The last two digits indicate publication order within the volume using a Base 36 numbering

system employing both numerals and letters. These two-number sets start with 00, 01, 02, 03, 04, $05,06,07,08,09,0 A, 0 B \ldots 0 Z$, followed by 10-1Z, 20-2Z, etc.

The CID Number appears on each page of the manuscript. The complete citation is used on the first page, and an abbreviated version on subsequent pages. Numbers in the index correspond to the last two digits of the six-digit CID Number. 


\title{
Contents
}

\section{Part One}

\author{
$\mathrm{xv}$ Conference Committee \\ xix Introduction
}

\section{PLENARY SESSION}

876302 An autonomous structural health monitoring solution (Plenary Paper) [8763-501]

C. A. Featherston, K. M. Holford, R. Pullin, J. Lees, M. Eaton, M. Pearson, Cardiff Univ. (United Kingdom)

876303 Biologically inspired large scale chemical sensor arrays and embedded data processing (Plenary Paper) [8763-502]

S. Marco, A. Gutiérrez-Gálvez, Univ. de Barcelona (Spain) and Institute for Bioengineering of Catalonia (Spain); A. Lansner, Kunliga Tekniska Högskolan (Sweden); D. Martinez, Ctr. National de la Recherche Scientifique (France); J. P. Rospars, Institut National de la Recherche Agronomique (France); R. Beccherelli, Consiglio Nazionale delle Ricerche (Italy); A. Perera, Univ. Politècnica de Catalunya (Spain); T. Pearce, Univ. of Leicester (United Kingdom); P. Vershure, Univ. Pompeu Fabra (Spain); K. Persaud, The Univ. of Manchester (United Kingdom)

\section{SESSION 1 ENERGY SCAVENGERS}

876305 A MEMS vibration energy harvester for automotive applications (Invited Paper) [8763-1] R. van Schaijk, R. Elfrink, J. Oudenhoven, V. Pop, Z. Wang, M. Renaud, IMEC/Holst Ctr. (Netherlands)

876306 Wearable and flexible thermoelectric generator with enhanced package [8763-2] L. Francioso, C. De Pascali, A. Taurino, P. Siciliano, IMM, Consiglio Nazionale Delle Ricerche (Italy); A. De Risi, Univ. of Salento (Italy)

$876307 \quad$ Hybrid energy storage system for wireless sensor node powered by aircraft specific thermoelectric energy harvesting [8763-3]

K. Thangaraj, Cardiff Univ. (United Kingdom); A. Elefsiniotis, S. Aslam, T. Becker, EADS Deutschland GmbH (Germany); U. Schmid, Vienna Univ. of Technology (Austria); J. Lees, C. A. Featherston, R. Pullin, Cardiff Univ. (United Kingdom)

876308 ZnO nanogenerators: energy generation through scavenging vibration, advantages of using a diode [8763-4]

J. Briscoe, N. Jalai, Queen Mary, Univ. of London (United Kingdom); P. Wooliams, M. Stewart, M. Cain, P. M. Weaver, National Physical Lab. (United Kingdom); S. Dunn, Queen Mary, Univ. of London (United Kingdom) 
876309 Ceramic joints for pressure sensors development [8763-5]

R. Novotný, R. Vlach, J. Kadlec, R. Kuchta, Brno Univ. of Technology (Czech Republic)

8763 OA Cu-Sn transient liquid phase wafer bonding for MEMS applications [8763-6]

C. Flötgen, M. Pawlak, EV Group (Austria); E. Pabo, EV Group Inc. (United States);

H. van de Wiel, G. R. Hayes, TNO (Netherlands); V. Dragoi, EV Group (Austria)

8763 OB Analysis of thermal vias in molded interconnect devices [8763-7]

J. Reitterer, F. Fidler, F. Saint Julien-Wallsee, TriLite Technologies GmbH (Austria); M. Barth, W. Eberhardt, U. Keßler, H. Kück, Hahn-Schickard-Institute for Micro Assembly Technology (Germany); U. Schmid, Vienna Univ. of Technology (Austria)

8763 OC Characterization of quartz-based package for RF MEMS [8763-8]

G. Sordo, A. Faes, G. Resta, J. Iannacci, Fondazione Bruno Kessler (Italy)

\section{SESSION 3 MATERIALS}

8763 OD Novel applications of piezoresistive thin film systems based on hydrogenated carbon [8763-9]

S. Biehl, C. Rumposch, C. Recknagel, Fraunhofer Institute for Surface Engineering and Thin

Films (Germany)

$8763 \mathrm{OE}$ Optical properties of copper oxide thin films as selective sensing principle for hydrogen sulfide detection [8763-10]

J. Kneer, Univ. Freiburg (Germany); M. Boxberg, Fraunhofer Institute for Physical Measurement Techniques (Germany); J. Wöllenstein, Univ. Freiburg (Germany) and Fraunhofer Institute for Physical Measurement Techniques (Germany)

$8763 \mathrm{OF}$ Electrically conductive $\mathrm{Pt}-\mathrm{Rh} / \mathrm{ZrO}_{2}$ and $\mathrm{Pt}-\mathrm{Rh} / \mathrm{HfO}_{2}$ nanocomposite electrodes for high temperature harsh environment sensors [8763-11]

S. C. Moulzolf, D. J. Frankel, M. Pereira da Cunha, R. J. Lad, Univ. of Maine (United States)

8763 OG Fabrication and properties of SmFe 2 -PZT magnetoelectric thin films [8763-12]

I. Giouroudi, Vienna Univ. of Technology (Austria); M. Alnassar, J. Kosel, King Abdullah Univ.

of Science and Technology (Saudi Arabia)

\section{SESSION 4 OPTICAL DEVICES AND SYSTEMS}

$8763 \mathrm{OH} \quad$ High-speed ultra-broad tuning MEMS-VCSELs for imaging and spectroscopy (Invited Paper) [8763-13]

V. Jayaraman, Praevium Research Inc. (United States); B. Potsaid, J. Jiang, Thorlabs Inc. (United States); G. D. Cole, Advanced Optical Microsystems (United States);

M. E. Robertson, C. B. Burgner, D. D. John, Praevium Research Inc. (United States);

I. Grulkowski, W. Choi, T. H. Tsai, J. Liu, Massachusetts Institute of Technology (United States); B. A. Stein, S. T. Sanders, Univ. of Wisconsin-Madison (United States); J. G. Fujimoto, Massachusetts Institute of Technology (United States); A. E. Cable, Thorlabs Inc. (United States) 
$8763 \mathrm{Ol}$ High-precision optoelectronic sensor device for monitoring fermentation kinetics and maceration of wine [8763-14]

F. Jiménez-Márquez, J. Vázquez, J. Úbeda, J. L. Sánchez-Rojas, Univ. de Castilla-La Mancha (Spain)

8763 0J Optical position feedback of quasi-static 2D MOEMS mirrors [8763-15]

A. Tortschanoff, M. Baumgart, D. Holzmann, M. Lenzhofer, Carinthian Tech Research AG (Austria); T. Sandner, Fraunhofer Institute for Photonic Microsystems (Germany); A. Kenda, Carinthian Tech Research AG (Austria)

\section{SESSION 5 FLUIDIC MEMS}

8763 OK Influence of fluid-structure interaction on microcantilever vibrations: applications to rheological fluid measurement and chemical detection (Invited Paper) [8763-16] I. Dufour, E. Lemaire, B. Caillard, H. Debéda, C. Lucat, IMS, Univ. Bordeaux (France); S. M. Heinrich, F. Josse, Marquette Univ. (United States); O. Brand, Georgia Institute of Technology (United States)

$8763 \mathrm{OL}$ Comparison of quartz tuning forks and AIN-based extensional microresonators for viscosity measurements in oil/fuel mixtures [8763-17]

J. Toledo, T. Manzaneque, J. Hernando-García, J. Vazquez, Univ. de Castilla-La Mancha (Spain); A. Ababneh, Yarmouk Univ. (India); H. Seidel, Saarland Univ. (Germany); M. Lapuerta, J. L. Sánchez-Rojas, Univ. de Castilla-La Mancha (Spain)

\section{SESSION 6 THERMAL SENSORS}

$8763 \mathrm{ON}$ Flexible hot-film anemometer arrays for flow measurements on curved structures [8763-19] T. Beutel, M. Schwerter, M. Leester-Schädel, A. Dietzel, S. Büttgenbach, Technische Univ. Braunschweig (Germany)

876300 Microthermal sensors for determining fluid composition and flow rate in fluidic systems [8763-20]

B. Schmitt, C. Kiefer, A. Schütze, Saarland Univ. (Germany)

8763 OP A high thermal resistance MEMS-based Pirani vacuum sensor chip [8763-21]

F. Dams, R. Schreiner, Regensburg Univ. of Applied Sciences (Germany)

\section{SESSION 7 MICROACTUATORS}

8763 OR Electromagnetic microactuators (Invited Paper) [8763-23]

S. Büttgenbach, A. T. Al-Halhouli, M. Feldmann, V. Seidemann, A. Waldschik, Technische Univ. Braunschweig (Germany)

8763 OS Thermal design of a tristable electromagnetic linear microactuator with high displacement and low actuation force for mass storage applications [8763-24]

X. Xu, H.-D. Ngo, P. Mackowiak, E. Obermeier, Technische Univ. Berlin (Germany);

D. Miletic, H. Gerdes, H. H. Gatzen, Leibniz Univ. Hannover (Germany) 
8763 OT Highly sensitive thermal actuators for temperature sensing [8763-25]

H. Steiner, Vienna Univ. of Technology (Austria); W. Hortschitz, Institute for Integrated Sensor Systems (Austria); M. Stifter, Vienna Univ. of Technology (Austria) and Institute for Integrated Sensor Systems (Austria); F. Keplinger, Vienna Univ. of Technology (Austria); T. Sauter, Institute for Integrated Sensor Systems (Austria)

\section{SESSION 8 RESONATORS}

8763 OU Design of high-efficiency vibration energy harvesters and experimental functional tests for improving bandwidth and tunability [8763-26]

A. Somà, G. De Pasquale, Politecnico di Torino (Italy)

$8763 \mathrm{OV}$ Fabrication of vertical nanowire resonators for aerosol exposure assessment [8763-27]

S. Merzsch, H. S. Wasisto, A. Stranz, Braunschweig Univ. of Technology (Germany); P. Hinze, T. Weimann, Physikalisch-Technische Bundesanstalt (Germany); E. Peiner, A. Waag, Braunschweig Univ. of Technology (Germany)

8763 OW Quality factor enhancement for resonant MEMS applying an analogue feedback circuit driven by a lock-in amplifier [8763-28]

M. Kucera, Vienna Univ. of Technology (Austria) and $\mathrm{AC}^{2} \mathrm{~T}$ research $\mathrm{GmbH}$ (Austria); F. Hofbauer, Vienna Univ. of Technology (Austria); T. Manzaneque, V. Ruiz, J. L. Sánchez-Rojas, Univ. de Castilla-La Mancha (Spain); A. Bittner, U. Schmid, Vienna Univ. of Technology (Austria)

8763 OX Multi-modal vibration based MEMS energy harvesters for ultra-low power wireless functional nodes [8763-29]

J. Iannacci, M. Gottardi, E. Serra, R. Di Criscienzo, Fondazione Bruno Kessler (Italy); A. Borrielli, M. Bonaldi, Istituto Nazionale di Fisica Nucleare (Italy) and Institute of Materials for Electronics and Magnetism, Nanoscience (Italy)

\section{SESSION 9 BIO-MEMS}

8763 OY All-silicon microforce sensor for bio applications [8763-30]

V. T. Stavrov, AMG Technology Ltd. (Bulgaria); A. A. Shulev, Institute of Mechanics (Bulgaria); C. M. Hardalov, Sofia Technical Univ. (Bulgaria); V. M. Todorov, Techproject (Austria); I. R. Roussev, Institute of Mechanics (Bulgaria)

$87630 Z$ Efficient nanoparticle filtering using bioinspired functional sufaces [8763-31] S. Busch, M. Ketterer, Univ. of Freiburg (Germany); X. Vinzenz, C. Hoffmann, Institute for Bioprocessing and Analytical Measurement Techniques (Germany); J. Wöllenstein, Univ. of Freiburg (Germany) and Fraunhofer Institute for Physical Measurement Techniques (Germany)

876311 A low complexity wireless microbial fuel cell monitor using piezoresistive sensors and impulse-radio ultra-wide-band [8763-33]

M. Crepaldi, A. Chiolerio, T. Tommasi, D. Hidalgo, G. Canavese, S. Stassi, Istituto Italiano di Tecnologia (Italy); D. Demarchi, F. C. Pirri, Istituto Italiano di Tecnologia (Italy) and Politecnico di Torino (Italy) 
876312 On a high-potential variable flexural stiffness device [8763-34]

M. Henke, G. Gerlach, Technische Univ. Dresden (Germany)

876315 A miniaturized linear shaker system for MEMS sensor characterization [8763-37]

J. Encke, W. Hortschitz, Institute for Integrated Sensor Systems (Austria); A. Kainz, H. Steiner, F. Keplinger, Vienna Univ. of Technology (Austria); T. Sauter, Institute for Integrated Sensor Systems (Austria)

876316 Controlled fabrication of advanced functional structures on the nanoscale by means of electron beam-induced processing [8763-38]

S. W. Schmidt, nanotools GmbH (Germany); J. Foucher, CEA-Leti (France); C. Penzkofer,

B. Irmer, nanotools GmbH (Germany)

876317 Rotational microactuator for microsurgery [8763-39]

M. Leester-Schädel, J.-W. Thies, T. Schubert, S. Büttgenbach, A. Dietzel, Technische Univ. Braunschweig (Germany)

876318 Simulation and fabrication of integrated polystyrene microlens in microfluidic system [8763-41]

Y. Fan, H. Li, D. Conchouso, I. G. Foulds, King Abdullah Univ. of Science and Technology (Saudi Arabia)

8763 1A Magnetic tunnel junction sensors with pTesla sensitivity for biomedical imaging [8763-43]

S. Cardoso, Inesc-MN (Portugal) and Instituto Superior Técnico (Portugal); L. Gameiro,

D. C. Leitao, F. Cardoso, Inesc-MN (Portugal); R. Ferreira, E. Paz, International Iberian Nanotechnology Lab. (Portugal); P. P. Freitas, INESC-MN (Portugal) and Instituto Superior Técnico (Portugal)

8763 1B Hydrogel plug for independent sample and buffer handling in continuous microchip capillary electrophoresis [8763-44]

D. Puchberger-Enengl, Vienna Univ. of Technology (Austria); M. Bipoun, Univ. of Bremen (Germany); M. Smolka, Vienna Univ. of Technology (Austria); C. Krutzler, Integrated Microsystems Austria GmbH (Austria); F. Keplinger, Vienna Univ. of Technology (Austria); M. J. Vellekoop, Univ. of Bremen (Germany)

8763 1C A new injection method for soil nutrient analysis in capillary electrophoresis [8763-45] M. Smolka, D. Puchberger-Enengl, Vienna Univ. of Technology (Austria); M. Bipoun, Univ. Bremen (Germany); G. Fercher, Vienna Univ. of Technology (Austria); A. Klasa, Warmia and Mazury Univ. in Olsztyn (Poland); C. Krutzler, Integrated Microsystems Austria GmbH (Austria); F. Keplinger, Vienna Univ. of Technology (Austria); M. J. Vellekoop, Univ. Bremen (Germany)

8763 1D Simulation and optimization of the magnetic field in an electroplated copper micro-coil [8763-46] M. Matar, Technische Univ. Braunschweig (Germany); A. T. Al-Halhouli, German Jordanian Univ. (Germany); S. Büttgenbach, A. H. Dietzel, Technische Univ. Braunschweig (Germany)

$8763 \mathrm{IF}$ Development of energy harvester system for avionics [8763-48]

Z. Hadas, V. Vetiska, Z. Ancik, C. Ondrusek, V. Singule, Brno Univ. of Technology (Czech Republic) 
8763 IG Optimized energy harvesting from mechanical vibrations through piezoelectric actuators, based on a synchronized switching technique [8763-49]

P. Tsampas, G. Roditis, V. Papadimitriou, P. Chatzakos, Innora S.A. (Greece); T.-H. Gan, TWI Technology Ctr., Ltd. (United Kingdom)

876311 CMOS compatible low-frequency aluminium nitride MEMS piezoelectric energy harvesting device [8763-51]

N. Jackson, R. O'Keeffe, Tyndall National Institute (Ireland); M. O'Neill, Analog Devices Inc. (Ireland); F. Waldron, A. Mathewson, Tyndall National Institute (Ireland)

$87631 \mathrm{~J}$ Comparison of low-power single-stage boost rectifiers for sub-milliwatt electromagnetic energy harvesters [8763-52]

G. D. Szarka, P. P. Proynov, B. H. Stark, S. G. Burrow, Univ. of Bristol (United Kingdom)

8763 1K Load optimised piezoelectric generator for powering battery-less TPMS [8763-53]

D. Blažević, E. Kamenar, S. Zelenika, Univ. of Rijeka (Croatia) and Ctr. for Micro and Nano Sciences and Technologies (Croatia)

8763 IL Flat inductors for human motion energy harvesting [8763-54]

J. Blums, G. Terlecka, I. Gornevs, A. Vilumsone, Riga Technical Univ. (Latvia)

$87631 \mathrm{M}$ Modeling, simulation and experimental testing of the MEMS thermoelectric generators in wide range of operational conditions [8763-55]

Z. Ancik, R. Vlach, L. Janak, P. Kopecek, Z. Hadas, Brno Univ. of Technology (Czech Republic)

\section{Part Two}

$87631 \mathrm{~N}$ Design and material aspects for thermoelectric energy harvesting devices in aircrafts [8763-56]

A. Elefsiniotis, N. Kokorakis, T. Becker, EADS IW Deutschland (Germany); U. Schmid, Vienna Univ. of Technology (Austria)

876310 A nano-power energy harvesting IC for arrays of piezoelectric transducers [8763-57] M. Dini, M. Filippi, A. Romani, Univ. of Bologna (Italy); V. Bottarel, G. Ricotti,

STMicroelectronics (Italy); M. Tartagni, Univ. of Bologna (Italy)

8763 IP Design, fabrication and characterization of a very low frequency piezoelectric energy harvester designed for heart beat vibration scavenging [8763-58]

M. Colin, S. Basrour, L. Rufer, TIMA Lab. (France)

$87631 Q \quad$ A miniaturised autonomous sensor based on nanowire materials platform: the SiNAPS mote [8763-59]

N. Koshro Pour, M. Kayal, Ecole Polytechnique Federal Lausanne (Switzerland); G. Jia,

B. Eisenhawer, F. Falk, Institute of PhotonicTechnology (Germany); A. Nightingale,

J. C. DeMello, Imperial College London (United Kingdom); Y. M. Georgiev, N. Petkov,

J. D. Holmes, M. Nolan, G. Fagas, Univ. College Cork (Ireland)

8763 is Design, fabrication and characterization of a micromachined piezoelectric energy harvester excited by ambient vibrations [8763-61]

A. B. Alamin Dow, Univ. of Toronto (Canada); A. Bittner, U. Schmid, Vienna Univ. of Technology (Austria); N. P. Kherani, Univ. of Toronto (Canada) 
$87631 \mathrm{~T} \quad$ Photovoltaic energy harvesting for smart sensor systems [8763-62]

M. Kasemann, Univ. of Freiburg (Germany); K. Rühle, Univ. of Freiburg (Germany) and Fraunhofer-Institute for Solar Energy Systems (Germany); K. M. Gad, Univ. of Freiburg (Germany); S. W. Glunz, Fraunhofer-Institute for Solar Energy Systems (Germany)

$87631 \mathrm{U}$ Parametrization of ambient energy harvesters for complementary balanced electronic applications [8763-63]

Y. Verbelen, A. Braeken, Erasmus Univ. College Brussels (Belgium); A. Touhafi, Erasmus Univ. College Brussels (Belgium) and Vrije Univ. Brussel (Belgium)

$87631 \mathrm{X}$ Investigation on the dielectric behavior of aluminum nitride thin films at different temperatures applying a time-zero approach [8763-66] M. Schneider, A. Bittner, U. Schmid, Vienna Univ. of Technology (Austria)

$87631 Y$ Interfacial adhesion between the iron fillers and the silicone matrix in magneto-rheological elastomers at high deformations [8763-67]

T. Pössinger, C. Bolzmacher, Commissariat à l'Energie Atomique (France); L. Bodelot, N. Triantafyllidis, École Polytechnique (France)

876312 Investigations on the high temperature compatibility of various adhesion layers for platinum [8763-68]

A. Ababneh, A. N. Al-Omari, Yarmouk Univ. (Jordan); M. Marschibois, D. Feili, H. Seidel, Saarland Univ. (Germany)

$876320 \quad 2-2$ composites based on [011]-poled relaxor-ferroelectric single crystals: from the piezoelectric anisotropy to the hydrostatic response [8763-69]

C. R. Bowen, Univ. Bath (United Kingdom); V. Y. Topolov, Southern Federal Univ. (Russian Federation); D. N. Betts, H. A. Kim, Univ. Bath (United Kingdom)

876321 Simulation and characterization of silicon nanopillar-based nanoparticle sensors [8763-71] H. S. Wasisto, S. Merzsch, K. Huang, A. Stranz, A. Waag, E. Peiner, Braunschweig Univ. of Technology (Germany)

876322 Simulation, design and fabrication of a planar micro thermoelectric generator [8763-72] S. Pelegrini, Fondazione Bruno Kessler (Italy) and Univ. Federal de Santa Catarina (Brazil); A. Adami, C. Collini, P. Conci, L. Lorenzelli, Fondazione Bruno Kessler (Italy); A. A. Pasa, Univ. Federal de Santa Catarina (Brazil)

876323 Advanced modeling of AIN-based micromachined energy harvesters driven by $\beta$-emitting radioisotopes [8763-73]

A. B. Alamin Dow, Univ. of Toronto (Canada); U. Schmid, Vienna Univ. of Technology (Austria); N. P. Kherani, Univ. of Toronto (Canada)

876324 Modeling methods of MEMS micro-speaker with electrostatic working principle [8763-74] D. Tumpold, M. Kaltenbacher, Univ. of Technology Vienna (Austria); C. Glacer, M. Nawaz, A. Dehé, Infineon Technologies AG (Germany)

876325 Experimental methodology to measure damping in microstructures by using the actuation force hysteresis curve [8763-75]

G. De Pasquale, A. Somà, Politecnico di Torino (Italy) 
876326 A large deflection model of silicon membranes for testing intrinsic stress of MEMS microphones by measuring pull-In voltage [8763-77]

F. Oesterle, Univ. of Erlangen-Nuremberg (Germany); F. Fink, H. Kuhn, A. Dehé, Infineon Technologies AG (Germany); R. Weigel, A. Koelpin, Univ. of Erlangen-Nuremberg (Germany)

876327 Analysis of local deformation effects in resistive strain sensing of a submicron-thickness AFM cantilever [8763-78]

J. D. Adams, Ecole Polytechnique Fédérale de Lausanne (Switzerland); C. H. Schwalb, M. Winhold, Goethe Univ. (Germany); M. Đukić, École Polytechnique Fédérale de Lausanne (Switzerland); M. Huth, Goethe Univ. (Germany); G. E. Fantner, École Polytechnique Fédérale de Lausanne (Switzerland)

876328 Magnetic circuit design for miniaturized magnetic shape memory alloy actuators [8763-79] C. Bolzmacher, Commissariat à l'Énergie Atomique (France)

876329 Exploiting infrared transparency of silicon for the construction of advanced MOEMS vibration sensors [8763-80]

W. Hortschitz, Institute for Integrated Sensor Systems (Austria) and Vienna Univ. of Technology (Austria); A. Kainz, Vienna Univ. of Technology (Austria); J. Encke, F. Kohl, Institute for Integrated Sensor Systems (Austria); H. Steiner, Vienna Univ. of Technology (Austria); M. Stifter, T. Sauter, Institute for Integrated Sensor Systems (Austria); F. Keplinger, Vienna Univ. of Technology (Austria)

$87632 \mathrm{~A}$ A resonance-based solar element: a numerical model and micro/nano technology application [8763-81]

P. Fiala, P. Drexler, D. Nespor, Brno Univ. of Technology (Czech Republic)

8763 2B Biomimetic MEMS sensor array for navigation and water detection [8763-82]

O. Futterknecht, Vienna Univ. of Technology (Austria); M. O. Macqueen, Aramis Technologies (Malaysia); S. Karman, Univ. Kebangsaan Malaysia (Malaysia) and Univ. of Malaya (Malaysia); S. Z. M. Diah, Univ. Kebangsaan Malaysia (Malaysia); I. C. Gebeshuber, Vienna Univ. of Technology (Austria), Aramis Technologies (Malaysia), and Univ. Kebangsaan Malaysia (Malaysia)

$87632 \mathrm{C}$ Simulation and design optimization of transparent heaters for spectroscopic micro cells [8763-83]

H. Völlm, J. Herrmann, Saarland Univ. (Germany); R. Maier, Friedrich Alexander Univ. Erlangen-Nuremberg (Germany); D. Feili, Saarland Univ. (Germany); V. Häublein, Fraunhofer Institute for Integrated Systems and Device Technology (Germany); H. Ryssel, Friedrich Alexander Univ. Erlangen-Nuremberg (Germany) and Fraunhofer Institute for Integrated Systems and Device Technology (Germany); H. Seidel, Saarland Univ. (Germany)

$87632 \mathrm{D}$ Flip-chip packaging of piezoresistive barometric pressure sensors [8763-84] T. Waber, Univ. of Applied Sciences - Munich (Germany); W. Pahl, M. Schmidt, EPCOS AG (Germany); G. Feiertag, Univ. of Applied Sciences - Munich (Germany); S. Stufler, EPCOS AG (Germany); R. Dudek, Fraunhofer-Institut für Elektronische Nanosysteme (Germany); A. Leidl, EPCOS AG (Germany) 
$87632 \mathrm{E} \quad$ A Lorentz force actuated magnetic field sensor with capacitive read-out [8763-85] M. Stifter, Vienna Univ. of Technology (Austria) and Institute for Integrated Sensor Systems (Austria); H. Steiner, A. Kainz, F. Keplinger, Vienna Univ. of Technology (Austria); W. Hortschitz, T. Sauter, Institute for Integrated Sensor Systems (Austria)

$87632 \mathrm{~F} \quad$ Mid-infrared rib waveguide absorption sensors based on Si [8763-86] V. Lavchiev, Johannes Kepler Univ. (Austria); C. Kristament, M. Brandstetter, G. Ramer, B. Lendl, Vienna Univ. of Technology (Austria); U. Hedenig, T. Grille, P. Irsigler, Infineon Technologies Austria AG (Austria); B. Jakoby, Johannes Kepler Univ. (Austria)

$87632 \mathrm{G}$ MEMS sensors for mm-range displacement measurements with sub-nm resolution [8763-87] V. T. Stavrov, AMG Technology Ltd. (Bulgaria); V. M. Todorov, Techproject (Austria); A. A. Shulev, Institute of Mechanics (Bulgaria); C. M. Hardalov, Sofia Technical Univ. (Bulgaria)

$87632 \mathrm{H} \quad$ Detection of bad indoor environment with a miniaturized gas sensor system [8763-88] J. Huber, Univ. of Freiburg (Germany) and Fraunhofer Institute for Physical Measurement Techniques IPM (Germany); R. Binninger, K. Schmitt, Fraunhofer Institute for Physical Measurement Techniques IPM (Germany); J. Wöllenstein, Univ. of Freiburg (Germany) and Fraunhofer Institute for Physical Measurement Techniques IPM (Germany)

$87632 \mathrm{~K}$ Optical actuation of silicon cantilevers: modelling and experimental investigation [8763-91] F. Jiang, A. Keating, M. Martyuink, D. Silva, L. Faraone, J. M. Dell, The Univ. of Western Australia (Australia)

$87632 \mathrm{~L} \quad$ MEMS-based silicon cantilevers with integrated electrothermal heaters for airborne ultrafine particle sensing [8763-92]

H. S. Wasisto, S. Merzsch, A. Waag, E. Peiner, Braunschweig Univ. of Technology (Germany)

$87632 \mathrm{M}$ Design and fabrication of a $5 \mathrm{MHz}$ ultrasonic phased array probe with curved transducer [8763-93]

J. Fischer, T. Herzog, S. Walter, H. Hever, Fraunhofer IZFP Dresden (Germany)

$87632 \mathrm{~N} \quad$ MEMS pressure sensor with maximum performances by using novel back-side direct-exposure concept featuring through glass vias [8763-94]

B. Mukhopadhyay, M. Fritz, P. Mackowiak, T. C. Vu, O. Ehrmann, K.-D. Lang, Technical Univ. of Berlin (Germany); H.-D. Ngo, Univ. of Applied Sciences Berlin (Germany)

$87632 \mathrm{P} \quad$ From nature to MEMS: towards the detection-limit of crickets' hair sensors [8763-96] A. M. K. Dagamseh, Yarmouk Univ. (Jordan) and Univ. of Twente (Netherlands)

$87632 Q \quad$ Counting x-ray line detector with monolithically integrated readout circuits [8763-97] T. Lohse, P. Krüger, Fraunhofer Institute for Non-Destructive Testing (Germany); H. Hever, Fraunhofer Institute for Non-Destructive Testing (Germany) and Technical Univ. of Dresden (Germany); M. Oppermann, Technical Univ. Dresden (Germany); H. Torlee, Fraunhofer Institute for Photonic Microsystems (Germany); N. Meyendorf, Fraunhofer Institute for Non-Destructive Testing (Germany) 
$87632 R \quad$ Design strategies of opto-mechanical micro oscillators for the detection of the ponderomotive squeezing [8763-98]

A. Borrielli, M. Bonaldi, Institute of Materials for Electronics and Magnetism, Nanoscience (Italy) and Istituto Nazionale di Fisica Nucleare (Italy); E. Serra, Univ. of Trento (Italy) and Istituto Nazionale di Fisica Nucleare (Italy); A. Bagolini, M. Boscardin, Michrotechnology Lab. FBK-CMM (Italy); F. S. Cataliotti, Univ. di Firenze (Italy) and European Lab. for Non-Linear Spectroscopy (Italy) and Istituto Nazionale di Fisica Nucleare (Italy); F. Marin, European Lab. for Non-Linear Spectroscopy (Italy) and Istituto Nazionale di Fisica Nucleare (Italy) and Univ. di Firenze (Italy); F. Marino, European Lab. for Non-Linear Spectroscopy (Italy) and Istituto Nazionale di Fisica Nucleare (Italy) and CNR-Istituto dei Sistemi Complessi (Italy); A. Pontin, G. A. Prodi, Istituto Nazionale di Fisica Nucleare (Italy) and Univ. di Trento (Italy)

876325 Measurement of the 1/f noise of lateral actuated MEMS with sidewall piezoresistors [8763-99]

V. Stavrov, AMG Technology Ltd. (Bulgaria); F. Kohl, T. Sauter, Institute for Integrated Sensor Systems (Austria); P. Philipov, Sofia Technical Univ. (Bulgaria)

$87632 U \quad$ MEMS pressure sensor fabricated by advanced bulk micromachining techniques [8763-101]

G. Vanko, Institute of Electrical Engineering (Slovakia); P. Hudek, J. Zehetner, Vorarlberg Univ. of Applied Sciences (Austria); J. Dzuba, Institute of Electrical Engineering (Slovakia); P. Choleva, Vorarlberg Univ. of Applied Sciences (Austria); M. Vallo, I. Rýger, T. Lalinský, Institute of Electrical Engineering (Slovakia)

$87632 \mathrm{~V}$ Shortening of the process chain by tactile inline measurement [8763-102]

L. Doering, N. Thronicke, C. Löbner, T. Frank, CiSMT (Germany); S. Reich, Gesellschaft für Fertigungstechnik und Entwicklung e.V. (Germany); S. Völlmeke, A. Steinke, CiSMT (Germany)

$87632 \mathrm{~W}$ Self-aligned single-mask fabrication process for electro-thermal microactuators using ICP-RIE [8763-104]

A. B. Alamin Dow, Univ. of Toronto (Canada); A. Gougam, Masdar Institute of Science and Technology (United Arab Emirates); N. P. Kherani, Univ. of Toronto (Canada);

I. W. Rangelow, Ilmenau Univ. of Technology (Germany)

$87632 \mathrm{X} \quad$ Microgalvanic nickel pulse plating process for the production of thermal actuators [8763$110]$

W. Hansal, Happy Plating GmbH (Austria); H. Steiner, Vienna Univ. of Technology (Austria); R. Mann, M. Halmdienst, Happy Plating GmbH (Austria); J. Schalko, F. Keplinger, Vienna Univ. of Technology (Austria)

$87632 Y \quad$ Control of cavitation density through gas and acoustic uniformity in a proximity megasonic pre-bond cleaning system [8763-111]

D. Dussault, E. Liebscher, ProSys Inc. (United States); F. Fournell, CEA-Leti, MINATEC (France); V. Dragoi, EV Group (Austria)

$87632 \mathrm{Z}$ Chemical microsensors based on hydrogels with adjustable measurement range [8763-103]

W. Haas, J. W. Bartha, W.-J. Fischer, Institute of Semiconductors and Microsystems (Germany); A. Richter, Technische Univ. Dresden (Germany) 
876330 Fabrication of an array-like freeform molding tool for UV-replication using a step and repeat process [8763-105]

J. Dunkel, Fraunhofer Institute for Applied Optics and Precision Engineering (Germany) and Friedrich-Schiller-Univ. Jena (Germany); F. Wippermann, A. Brückner, A. Reimann, A. Bräuer, Fraunhofer Institute for Applied Optics and Precision Engineering (Germany)

876331 Fabrication of double-sided micro structured mechanical sensors based on SU-8 resist using a new micro molding process [8763-106]

A. Oerke, S. Büttgenbach, A. Dietzel, Technische Univ. Braunschweig (Germany)

876332 Multilayer micromachined bandpass filter for $\mathrm{L} / \mathrm{S}$ band satellite communication systems [8763-107]

A. Q. A. Qureshi, Fondazione Bruno Kessler (Italy); L. Pelliccia, Univ. of Perugia (Italy);

S. Colpo, J. Iannacci, P. Farinelli, B. Margesin, Fondazione Bruno Kessler (Italy)

876333 Contour and flexure-actuated in-plane modes of AIN-based piezoelectric vibrating MEMS [8763-108]

V. Ruiz-Díaz, T. Manzaneque, J. Hernando-García, Univ. de Castilla-La Mancha (Spain); A. Ababneh, Yarmouk Univ. (India); M. Kucera, Vienna Univ. of Technology (Austria) and $\mathrm{AC}^{2} \mathrm{~T}$ research $\mathrm{GmbH}$ (Austria); A. N. Al-Omari, Yarmouk Univ. (India); A. Bittner, U. Schmid, Vienna Univ. of Technology (Austria); H. Seidel, Saarland Univ. (Germany);

J. L. Sánchez-Rojas, Univ. de Castilla-La Mancha (Spain)

876334 Pressure dependence of the quality factor of piezoelectrically driven AIN/Simicrocantilevers [8763-109]

A. Ababneh, A. N. Al-Omari, Yarmouk Univ. (Jordan); H. C. Qiu, Saarland Univ. (Germany); T. Manzaneque, J. Hernando, J. Sánchez-Rojas, Univ. de Castilla-La Mancha (Spain);

A. Bittner, U. Schmid, Vienna Univ. of Technology (Austria); H. Seidel, Saarland Univ.

(Germany)

876336 Formation of a deposit on workpiece surface in polishing nonmetallic materials [8763-113] Y. D. Filatov, V. N. Bakul Institute for Superhard Materials NASU (Ukraine); G. Monteil, L'Institut FEMTO-ST (France); V. I. Sidorko, O. Y. Filatov, V. N. Bakul Institute for Superhard Materials NASU (Ukraine)

876337 A closed-loop system for frequency tracking of piezoresistive cantilever sensors [8763-114] H. S. Wasisto, Q. Zhang, S. Merzsch, A. Waag, E. Peiner, Braunschweig Univ. of Technology (Germany)

876338 Simulation of thick film PZT actuators with interdigitated electrodes [8763-115] M. M. Zaki, S. Zähringer, N. Schwesinger, Technische Univ. München (Germany)

Author Index 
Proc. of SPIE Vol. $8763876301-14$

Downloaded From: https://www.spiedigitallibrary.org/conference-proceedings-of-spie on 26 Apr 2023 Terms of Use: https://www.spiedigitallibrary.org/terms-of-use 


\title{
Conference Committee
}

\author{
Symposium Chair
}

Thomas Becker, EADS Innovation Works (Germany)

Symposium Cochairs

Christos Tsamis, National Center for Scientific Research Demokritos (Greece)

Gerhard Kröłz, University of Applied Sciences in Kempten (Germany)

Symposium Local Chair

Marc Belleville, CEA-Leti (France)

Conference Chair

Ulrich Schmid, Technische Universität Wien (Austria)

Conference Cochairs

José Luis Sánchez de Rojas Aldavero, Universidad de Castilla-La Mancha (Spain)

Monika Leester-Schaedel, Technische Universität Braunschweig (Germany)

Conference Programme Committee

Ali Badar M. Alamin Dow, University of Toronto (Canada) Eduard Arzt, Leibniz-Institut für Neue Materialien GmbH (Germany) Joan Bausells, Centro Nacional de Microelectrónica (Spain) Christian Bolzmacher, Commissariat à l'Énergie Atomique (France) Carles Cané, Centro Nacional de Microelectrónica (Spain) Viorel Dragoi, EV Group (Austria)

Guido Faglia, Universitá degli Studi di Brescia (Italy)

Georg E. Fantner, Ecole Polytechnique Fédérale de Lausanne (Switzerland)

Carles Ferrer Ramis, Universitat Autònoma de Barcelona (Spain)

Pavel J. Fiala, Brno University of Technology (Czech Republic)

Maximilian Fleischer, Siemens AG (Germany)

Friedrich Franek, AC $2 T$ Research $\mathrm{GmbH}$ (Austria)

Sören Fricke, Robert Bosch GmbH (Germany)

Gerald Gerlach, Technische Universität Dresden (Germany) 
Katia M. Grenier, Centre National de la Recherche Scientifique (France)

Moustapha Hafez, Commissariat à l'Énergie Atomique (France)

Henning Hever, Fraunhofer-Institut für Zerstörungsfreie Prüfverfahren (Germany)

Arno C. Hoogerwerf, Centre Suisse d'Electronique et de Microtechnique SA (Switzerland)

Jacopo lannacci, Fondazione Bruno Kessler (Italy)

Enrique Iborra, Universidad Politécnica de Madrid (Spain)

Bernhard Jakoby, Johannes Kepler Universität Linz (Austria)

Konrad Kapser, Infineon Technologies AG (Germany)

Roy Knechtel, X-FAB Semiconductor Foundries AG (Germany)

Andreas Kugi, Technische Universität Wien (Austria)

Robert J. Lad, University of Maine (United States)

Jeong-Bong Lee, The University of Texas at Dallas (United States)

Michael Leitner, ams AG (Austria)

Anita Lloyd Spetz, Linköping University (Sweden)

Dean P. Neikirk, The University of Texas at Austin (United States)

Sergio P. Pacheco, Freescale Semiconductor, Inc. (United States)

Erwin Peiner, Technische Universität Braunschweig (Germany)

Thilo Sauter, Austrian Academy of Sciences (Austria)

Gabriele Schrag, Technische Universität München (Germany)

Andreas Schütze, Universität des Saarlandes (Germany)

Pietro Siciliano, Istituto per la Microelettronica e Microsistemi (Italy)

Christos Tsamis, National Center for Scientific Research Demokritos

(Greece)

Gabriel Vanko, Slovak Academy of Sciences (Slovakia)

Michael J. Vellekoop, Universitäł Bremen (Germany)

Jürgen Wöllenstein, Fraunhofer-Institut für Physikalische Messtechnik (Germany)

\section{Session Chairs}

Plenary Sessions

Marc Belleville, CEA-Leti (France)

Christos Tsamis, National Center for Scientific Research Demokritos (Greece)

1 Energy Scavengers

Jacopo lannacci, Fondazione Bruno Kessler (Italy)

Ulrich Schmid, Technische Universität Wien (Austria)

2 Packaging

Jürgen Wöllenstein, Fraunhofer-Institut für Physikalische Messtechnik (Germany)

Robert J. Lad, University of Maine (United States) 
3 Materials

Ulrich Schmid, Technische Universität Wien (Austria)

Arno C. Hoogerwerf, Centre Suisse d'Electronique et de Microtechnique SA (Switzerland)

$4 \quad$ Optical Devices and Systems

Jürgen Wöllenstein, Fraunhofer-Institut für Physikalische Messtechnik (Germany)

Erwin Peiner, Technische Universität Braunschweig (Germany)

5 Fluidic MEMS

José Luis Sánchez de Rojas Aldavero, Universidad de Castilla-La Mancha (Spain)

Pavel J. Fiala, Brno University of Technology (Czech Republic)

6 Thermal Sensors

Monika Leester-Schädel, Technische Universität Braunschweig (Germany)

Gerald Gerlach, Technische Universität Dresden (Germany)

7 Microactuators

Jacopo Iannacci, Fondazione Bruno Kessler (Italy)

Monika Leester-Schädel, Technische Universität Braunschweig (Germany)

8 Resonators

Andreas Schütze, Universität des Saarlandes (Germany)

Gerald Gerlach, Technische Universität Dresden (Germany)

9 Bio-MEMS

Erwin Peiner, Technische Universität Braunschweig (Germany) Jonathan Adams, Ecole Polytechnique Fédérale de Lausanne (Switzerland) 
Proc. of SPIE Vol. $8763876301-18$

Downloaded From: https://www.spiedigitallibrary.org/conference-proceedings-of-spie on 26 Apr 2023 Terms of Use: https://www.spiedigitallibrary.org/terms-of-use 


\section{Introduction}

The conference Smart Sensors, Actuators and MEMS took place in Grenoble, France from April 24th to April 26th 2013 . One hundred and fifteen contributions from Europe. America and Asia were accepted and grouped into 10 sessions including a poster session. The interdisciplinary spirit of the event was displayed by a wide range of topics based on the latest results which were achieved in the research and development areas of precision engineering and MEMS. Therefore, sessions focused on material and fabrication aspects, on micromachined sensors and actuators for the determination of biological, and physical and chemical quantities as well as on reliability issues. Moreover optical and RF MEMS have been presented and more application oriented topics such as energy scavengers, microfluidic systems, and low power management systems, were discussed. Due to this broad range of topics, researchers coming from academia and industry, with their specific backgrounds, created a very stimulating atmosphere for the exchange of new ideas.

Besides the high quality of the oral and poster presentations I would like to highlight the 4 invited presentations, given by Rob van Schaijk from IMEC, Belgium, on MEMS-based vibrational energy harvesters focusing automotive applications, by Vijaysekhar Jayaraman, Praevium Research Inc., United States, on MEMS-tunable VCSEL for imaging and spectroscopy, by Isabelle Dufour, University of Bordeaux, France, on the fluid-structure interaction of vibrating microcantilevers and last, but not least, by Stephanus Büttgenbach, Technische Universität Braunschweig, Germany, on electromagnetic microactuators.

I would like to thank all participants for their individual contributions which made the conference a successful event in the international conference calendar.

Special thanks go to Christos Tsamis, Gerhard Krötz and Thomas Becker for organising the symposium, and to my Co-Chairs José Luis Sánchez de Rojas Aldavero (Univ. Castilla-La Mancha, Ciudad Real, Spain) and Monika LeesterSchädel (Technische Universität Braunschweig, Germany). Finally I would like to thank the Programme Committee for doing the reviews and acting partly as session chairs.

Ulrich Schmid 
Proc. of SPIE Vol. $8763876301-20$

Downloaded From: https://www.spiedigitallibrary.org/conference-proceedings-of-spie on 26 Apr 2023 Terms of Use: https://www.spiedigitallibrary.org/terms-of-use 